\title{
Human metapneumovirus in the preterm neonate: current perspectives
}

This article was published in the following Dove Press journal:

Research and Reports in Neonatology

28 July 2016

Number of times this article has been viewed

\author{
Nathalie L Maitre' \\ John VWilliams ${ }^{2}$ \\ 'Center for Perinatal Research, \\ Department of Pediatrics, \\ Department of Pediatrics, Nationwide \\ Children's Hospital, Columbus, $\mathrm{OH}$, \\ ${ }^{2}$ Department of Pediatrics, University \\ of Pittsburgh School of Medicine, \\ Children's Hospital of Pittsburgh \\ of University of Pittsburgh Medical \\ Center, Pittsburgh, PA, USA
}

\begin{abstract}
Premature birth ( $<37$ weeks gestation) occurs in $\sim 11 \%$ of all births in the US. These infants are at risk of chronic lung disease and respiratory conditions, including bronchopulmonary dysplasia. Respiratory viruses are important causes of acute respiratory illness (ARI) in preterm infants, leading to rehospitalization, increased health care burden, and long-term morbidity. Human metapneumovirus (HMPV) is a paramyxovirus discovered in 2001 that is related to respiratory syncytial virus. Epidemiologic studies show that HMPV is a leading cause of ARI in children and adults worldwide. Prematurity is a major risk factor for severe HMPV disease, requiring hospitalization. Moreover, limited data suggest that HMPV infection during infancy is associated with asthma and recurrent wheezing, which are common long-term pulmonary complication of prematurity. HMPV causes nosocomial outbreaks of ARI in hospitals and long-term care facilities, although there are few studies of the prevalence of HMPV in neonatal intensive care unit populations. HMPV is a common and important virus in premature infants, and caregivers for preterm infants should consider this virus in patients with acute respiratory symptoms.
\end{abstract}

Keywords: prematurity, chronic lung disease, human metapneumovirus, bronchiolitis, BPD

\section{Human metapneumovirus}

Human metapneumovirus (HMPV) was first reported in 2001 by Dutch investigators who collected a number of unidentified virus isolates from children with lower respiratory infection (LRI) over a 20 -year period. ${ }^{1}$ Electron microscopy, biochemical studies, and sequence analysis of the virus genome identified it as a member of the Pneumovirus subfamily of the Paramyxoviridae that includes respiratory syncytial virus (RSV). HMPV is most closely related by sequence homology to avian meta pneumovirus (AMPV) type C. AMPV, discovered in 1979, is an important agricultural pathogen of poultry, causing severe respiratory disease in chickens and turkeys. ${ }^{2}$ Evolutionary analysis suggested that HMPV diverged from AMPV type C several hundred years ago. ${ }^{3-5}$ However, birds cannot be productively infected with HMPV, indicating that while the virus had a zoonotic origin, it has evolved to become an established human pathogen. ${ }^{6}$

Phylogenetic analysis of HMPV genes defines two major genetic subgroups of HMPV, designated $\mathrm{A}$ and $\mathrm{B}$, each with two minor subgroups. ${ }^{3-5,7}$ Longitudinal epidemiologic surveillance identified changes in subgroup dominance over time, suggesting that subtle changes between subgroups facilitate reinfection. ${ }^{8}$ Reinfection with either homologous or heterologous strains of HMPV occurs readily, even during early childhood. ${ }^{9-11}$ It is not
Correspondence: Nathalie L Maitre Department of Neonatology, 700 Children's Drive, Columbus, $\mathrm{OH} 43205$, USA

Tel + I 6147224559

Fax + I 614 722 454I

Email Nathalie.Maitre@

nationwidechildrens.org 
clear whether the ability of HMPV to reinfect humans is due to infections with different subgroup viruses that are antigenically distinct, incomplete or waning immunity, or $\mathrm{CD}^{+} \mathrm{T}$-cell impairment induced by respiratory virus infections. ${ }^{12}$ Serum neutralizing titers in adults appear to correlate with risk of reinfection. ${ }^{13}$ There are no definitive human data determining the degree of cross-protection between different HMPV subgroups. Animal studies show that these subgroups are not fully antigenically distinct and that there is cross-protective immunity. ${ }^{7,14-16}$ Therefore, similar to RSV, a single-antigen vaccine or prophylactic antibody would suffice.

HMPV infections occur in annual epidemics during the late winter and early spring months in temperate locations such as North America and Europe. The HMPV season overlaps with those of RSV and influenza viruses, but the peak incidence of HMPV typically occurs 1-2 months later than the peak of RSV. Prospective surveillance studies conducted over 25 years showed that HMPV was present in every season, although the year-to-year prevalence varied. ${ }^{9,17}$ Different genetic subgroups of HMPV frequently circulate during the same winter season, although one subgroup may predominate in a given year. ${ }^{8,17}$ Viruses from each subgroup are capable of causing severe LRI, and different subgroup viruses have not been associated convincingly with differing severity of disease. ${ }^{18,19}$ In most studies of patients with acute respiratory tract infection, the percentage of HMPV detection varies from $6 \%$ to $25 \%$. HMPV infection usually causes clinical disease; the virus is rarely detected in asymptomatic children., ${ }^{9,20-26}$ Studies of hospitalized and outpatient children worldwide have found HMPV to be associated with $6 \%-40 \%$ of acute respiratory illness (ARI) in a given season..$^{9,17,24,27-43} \mathrm{HMPV}$ is usually ranked second after RSV in most studies and has prevalence comparable to or greater than that of influenza or parainfluenza viruses (PIV). ${ }^{24,25,32}$

Hospitalization of children for HMPV infection occurs primarily in the first year of life, although many studies report that the peak age of hospitalization for HMPV is between 6 and 12 months of age and thus later than the peak age of hospitalization for RSV at 2-3 months. ${ }^{24,30,41,44-46}$ Males appear to be at greater risk of LRI due to HMPV compared with females, similar to sex difference in severity observed for other respiratory viruses. HMPV infections are more severe in patients with underlying medical conditions such as asthma, prematurity, cardiopulmonary disease, or immune compromise. , $22,24,27,28,32,37,40,46,47$ Importantly, adults can be productively reinfected with HMPV throughout life, and thus family members and care providers are potential vectors to transmit infection to young infants. ${ }^{48,49}$

\section{Premature infants and respiratory viruses}

Approximately $11 \%$ of live births in the US and Europe occur at $<37$ weeks of gestation. ${ }^{50}$ In addition, preterm birth is more common in certain populations, notably African-Americans. ${ }^{50}$ These preterm infants are at risk of significant respiratory morbidity, especially during the first year, typically recurrent or chronic wheezing or recurrent ARI. ${ }^{51,52}$ One prospective cohort study followed 124 very-low-birth-weight (VLBW $<1,500 \mathrm{~g}$ ) premature infants. At 1 year of age, $9 \%$ of the infants had been diagnosed with asthma, $11 \%$ had been hospitalized for ARI, and nearly half had required more than one health care visit. ${ }^{51}$ Another group evaluated a cohort of 28 VLBW infants with bronchopulmonary dysplasia (BPD) at a mean age of 9.5 years. ${ }^{52}$ Children with BPD, compared to matched VLBW controls without BPD, had higher rates of chronic respiratory symptoms ( $36 \%$ vs $8 \%$ ), higher rates of asthma ( $21 \%$ vs $0 \%$ ), and lower lung function by formal pulmonary function testing. A study of 797 preterm infants found that the frequency of chronic respiratory disease correlated inversely with gestational age and weight at birth, displayed a male predominance, and was more common in those who meet criteria for the diagnosis of BPD. ${ }^{53}$ Depending on differences in definition, race/ethnicity, and clinical management, $\sim 35 \%-45 \%$ of infants born before 28 weeks of gestation develop BPD. ${ }^{54}$ A large California state database study of $>263,000$ infants born prematurely between 1992 and 2000 found that $15 \%$ required at least one rehospitalization within the first year of life, most commonly with ARI. ${ }^{55}$ Notably, only $\sim 23 \%$ of the readmits for ARI were due to RSV, while the rest were other infectious causes. Numerous studies document an increased risk of LRI due to respiratory viruses in premature infants, though many studies focus on RSV. ${ }^{56-59}$ In preterm infants, respiratory viral LRI in the first years are later associated with long-term pulmonary consequences and diminished lung function. ${ }^{60-63}$

\section{Respiratory viruses in the neonatal intensive care unit}

Preterm infants are especially vulnerable to respiratory infections. RSV has been the virus of primary concern to neonatologists, with HMPV rarely recognized as an important source of morbidity in this population. HMPV has seldom been documented in the neonatal intensive care unit (NICU). However, viral infections often are not recognized as either causative or complicating factors in NICU patients' respiratory illnesses, except during virulent and rapidly contained 
outbreaks. Adenovirus and rhinovirus, for example, have been implicated in such isolated events. ${ }^{64,65}$ Thus, clinicians may not test for community respiratory viruses in a closed NICU, among a population of infants already at risk of respiratory symptoms due to lung disease associated with prematurity. Some studies suggest that apart from nosocomial outbreaks, viral respiratory infections are uncommon in the NICU. In one of the largest studies of viral infections in the NICU, including 5,396 infants admitted over a 12-year period, only 51 had a viral infection ( $29 \%$ of these RSV), representing $\sim 5 \%$ of all documented infections. ${ }^{66}$ In a report of postmortem autopsies of NICU infants who died of respiratory illness, none had HMPV or RSV. ${ }^{63}$ However, there are few published prospective studies of viral ARI in the NICU. Moreover, the absence of documented HMPV in the available data may simply be due to the recent discovery of HMPV and use of viral culture in many studies, since sensitive detection of HMPV requires RT-PCR (reverse transcription polymerase chain reaction). ${ }^{67}$ The recent VIRIoN-I study used multiplex PCR to show that $6 \%$ of 135 NICU patients evaluated and treated for late-onset sepsis due to respiratory symptoms had a viral infection. ${ }^{68} \mathrm{RSV}$ has been reported in numerous outbreaks of nosocomial NICU infection. ${ }^{69-75}$ Thus, the prevalence of community respiratory viruses in NICU populations is likely underappreciated. Future studies using routine screening with PCR or other molecular diagnostic methods will likely allow the detection of nosocomial HMPV infections as well.

\section{HMPV in preterm infants}

Preterm infants remain at high risk of morbidity from viral infections even after discharge, with readmissions and emergency department visits for ARI representing the majority of health care costs in the first year. ${ }^{51,55,56}$ Since the highest rates of hospitalization for HMPV are during the first year of life, it is likely in this age range that the greatest burden of HMPV LRI occurs among premature infants. ${ }^{24,32}$ The presenting symptoms of HMPV are often similar to those of RSV (apnea, cough, increased respiratory rate, wheezing, retractions). ${ }^{9,24}$ However, prematurity may contribute to a more frequent severe presentation of HMPV. A large prospective study of $>10,000$ children in three US cities found that of children evaluated in the emergency department, HMPV-positive subjects were more likely to have been born prematurely than HMPVnegative children ( $13 \%$ vs $11 \%, P=0.009)$. Similarly, hospitalized HMPV-positive children were more likely to be premature than HMPV-negative subjects (24\% vs $16 \%, P=0.006) .{ }^{24}$ A Brazilian 1-year cohort study of 303 premature infants identified 461 episodes of LRI and detected HMPV in $17 \%$ of these illnesses, half of which required hospitalization. ${ }^{57}$ In a longitudinal study of Spanish children hospitalized for LRI, HMPV was more frequently identified in preterm than term infants $(P=0.017) .^{76}$ HMPV was also detected in $9.5 \%$ of recurrent wheezing episodes in preterm infants. Numerous other studies have identified prematurity as a risk factor for hospitalization for HMPV infection. . $4,28,31,32,47$

HMPV respiratory illness, when recognized, is also associated with substantial morbidity, with at least one report of HMPV infection in a premature infant requiring extracorporeal membrane oxygenation support. ${ }^{77}$ In a study comparing clinical features and risk factors for HMPV with RSV, HMPV was associated with more severe disease in premature infants, with more preterm infants hospitalized with HMPV than RSV (21.3\% vs $12.4 \%$, respectively). ${ }^{78}$ In the outpatient clinic setting, all gestational age groups were equally represented for RSV and HMPV. However, hospitalized infants with severe HMPV were more likely to be born at earlier gestational ages than the late preterm period $(P=0.002)$. Significantly more infants who received palivizumab were HMPV, rather than RSV, positive (11.3\% vs $2.0 \%$, respectively). However, this finding may simply point to palivizumab receipt as a marker of extreme prematurity and is consistent with the lack of neutralizing activity by palivizumab against HMPV in vitro or in vivo. ${ }^{79}$ There are no published data regarding a protective effect of maternally derived antibodies on the incidence and severity of HMPV in neonates. However, infants with high levels of maternally acquired antibodies against the related viruses RSV and PIV type 3 are better protected against lower respiratory tract illness than those with lower levels. ${ }^{80,81}$ Infants do have maternally derived HMPV-specific antibodies at birth that wane during the first year of life. ${ }^{82,83}$ Thus, it is likely that infants born before the majority of maternal antibody are transported across the placenta in the third trimester will have diminished protection against HMPV. Moreover, this would present a challenge for a strategy of maternal vaccination, since vaccine-induced antibodies would not be present in the highest risk infants born before 28-32 weeks. $^{84}$

Overall, prematurity conferred the greatest odds ratio for severe HMPV disease (13.97, 95\% confidence interval: 1.50-130.0), far more than all other risk factors for severity of HMPV combined (female sex, genotype of HMPV, household crowding). Prematurity only conferred an odds ratio of 3.08 (95\% confidence interval: 1.63-5.83) for severe RSV disease, suggesting that premature infants may be at 
greater risk of severe HMPV disease. ${ }^{77}$ The increased severity of HMPV in preterm infants persisted after the first year, with pediatric intensive care data demonstrating that $34 \%$ of hospitalized infants with HMPV were preterm and had significantly worse hypoxemia, increased need for ventilation, and longer hospitalizations. ${ }^{85}$

Simultaneous coinfection with HMPV and RSV has been described. Dual infection with RSV and HMPV increased the risk of severe disease and pediatric intensive care unit admission compared to RSV alone in one small study, ${ }^{86}$ but this finding was not confirmed by subsequent larger reports. ${ }^{19,87-89}$

Consequences of HMPV infection on lung remodeling may also be worse than those of RSV for preterm infants. Pulmonary function testing at 1 year done on preterm infants who experienced LRI demonstrated differential effects of HMPV, RSV and other viruses on lung function. HMPV LRI were associated with clinically significant increases in airway resistance, which were worse than in $\operatorname{RSV} \operatorname{LRI}(P=0.002) .{ }^{61}$ HMPV may therefore have more severe short- and long-term consequences in preterm infants than term infants, without the current recognition or treatment options available for $\mathrm{RSV}^{58}$ An investigation of possible reasons for the differential effects of HMPV on the context of prematurity may provide insight into mechanisms and future therapeutic strategies.

The increased susceptibility of preterm infants to viral infection is incompletely understood and may involve a combination of prenatal and postnatal inflammatory conditions, immunologic immaturity, and genetics. ${ }^{62}$ In mouse models of prematurity, the degree of maturation of the immune system at the time of infection can influence response to initial and subsequent viral challenges. Preterm infants exhibit immature but also dysfunctional humoral immune responses with limited or inefficient repertoire formation and low IgG levels in the first 6 months. ${ }^{90}$ While leukocytes increase throughout gestation, the increase in $\mathrm{CD}^{+}$cells occurs in inverse proportion to an increase in $\mathrm{CD}^{+}$cells, which are often dysregulated, resulting in a functional immunosuppression. The inflammatory milieu is also postulated to increase susceptibility to infection with dysfunctional shifts in Th1/ Th2 balance and long-term effects on cytokine responses to infection.

In the case of HMPV, this altered inflammatory response has been noted in formerly hospitalized preterm children. One study reported a lower IFN $\gamma / \mathrm{IL}-4$ ratio (thus increased Th2 bias) in term infants infected with HMPV. ${ }^{91}$ In contrast, another study found that term infants hospitalized with HMPV infection had increased IFN $\gamma$, CCL5 and IL-10 levels, with increased $\mathrm{Th} 1 / \mathrm{Th} 2$ ratios compared to uninfected controls, but preterm infants exhibited minimal cytokine responses and no elevation in IFN $\gamma / \mathrm{IL}-4$ ratio. ${ }^{85}$

Alterations in the preterm microbiome due to frequent antibiotic exposures and delayed or limited feedings of maternal milk have also been hypothesized to play a role in immune system dysfunction. While evidence exists for a role of the microbiome in gut and lung immune susceptibility to bacterial pathogens or diseases such as necrotizing enterocolitis or pneumonia, it is unclear at this time whether a similar association exists with LRI-causing viruses or HMPV.

The increased severity of viral diseases and likelihood of pathological responses to viral illness are associated with disruption of normal development of the lung and the immune system. In particular, abnormal postnatal lung growth and iatrogenic lung injury may contribute to respiratory disease of prematurity. Preterm infants are at risk of significant respiratory morbidity in the first year of life but also at school age, ${ }^{92}$ when they present with symptoms similar to those of reactive airways disease, and upper or lower respiratory tract infections. ${ }^{51}$ Infants born at lower gestational ages are more likely to experience these morbidities, especially if they have BPD. While BPD is incompletely characterized, large prospective studies have demonstrated a pro-/anti-inflammatory cytokine imbalance, ${ }^{93}$ which could influence the pathogenesis of HMPV infection. Furthermore, extremely preterm infants with BPD are often discharged home on supplemental oxygen to support lung growth and development. However, hyperoxia can increase the severity of viral illnesses through exaggerated inflammatory responses to infection. ${ }^{94,95}$

While BPD is often associated with a high burden of morbidity and health care utilization after discharge from the NICU, even preterm infants without BPD exhibit more severe symptoms than term infants, such as more days of cough and wheeze after LRI. This may be related to lung injury during the perinatal period (even in the absence of infection), as $78 \%$ of children born at $<26$ weeks of gestation have evidence of airway obstruction, ventilation inhomogeneity, gas trapping, and airway hyperresponsiveness at 11 years of age. ${ }^{60,96}$ Preterm infants with similar lung function at 36 weeks postmenstrual age will differentially develop increased airway resistance at 1 year if they experience LRI in infancy. ${ }^{62}$

The immune system of preterm infants may play a role not only in susceptibility to HMPV but also in the severity of response. In particular, low levels of IFN $\gamma$ in cord blood are associated with childhood wheezing and atopy. It is hypothesized that the ability to have an initial increase in 
IFN $\gamma$ in response to the first presentation of a virus may limit excessive antigen presenting cell function and allow for protective immune response and viral clearance without immunopathogenesis. Two reports suggest that HMPV infection during infancy is associated with asthma or impaired lung function later in life. ${ }^{61,97}$ Preterm infants with poor initial IFN $\gamma$ responses may therefore have more severe symptoms upon LRI viral infections in infancy and beyond. Finally, a genetic susceptibility to morbidity after RSV infection may also contribute to severity of disease after LRI, ${ }^{98}$ and it is possible that such associations exist with HMPV.

\section{Treatment and prevention of HMPV}

For infants who require hospitalization, the primary therapies are supplemental oxygen and intravenous hydration. Extracorporeal membrane oxygenation support has been used in cases of respiratory failure refractory to mechanical ventilation. ${ }^{77,99}$ There are anecdotal reports of the empiric use of bronchodilators and corticosteroids, but there are no controlled trials of these medications for HMPV and no data to support efficacy. Bronchodilator and corticosteroid treatment appeared to offer benefit in experimentally infected cotton rats. ${ }^{100}$ Aerosolized ribavirin is the only currently licensed antiviral agent for treatment of RSV. Ribavirin and polyclonal human immunoglobulin exhibited in vitro virus-inhibiting activity against HMPV. ${ }^{101}$ However, there are no published animal or human data for these interventions. Anecdotal reports exist of ribavirin use in profoundly immunocompromised HMPV-infected patients, usually in conjunction with intravenous immunoglobulin, but there are no controlled data, and so this therapy should be considered experimental. ${ }^{102-107}$

A number of candidate vaccines against HMPV have been tested using animal models. Recombinant chimeric bovine/human PIV type 3 and Bacillus Calmette-Guérin vaccines expressing HMPV fusion (F) protein were immunogenic and protective in rodents ${ }^{108,109}$ Investigators have generated recombinant HMPV strains that lack various genes or that possess avian metapneumovirus gene insertions. ${ }^{110-113}$ Many of these recombinant viruses caused attenuated infection in rodents or nonhuman primates but were highly immunogenic, inducing neutralizing antibodies and protection against challenge with wild-type HMPV. Virus-like particles can be generated by expressing the viral fusion and matrix genes in mammalian cells to produce enveloped particles that are morphologically similar to viruses, but contain no genome and are noninfectious. ${ }^{114}$ These particles are effective at inducing B- and T-cell responses in animal models and confer protection against viruses of both subgroups. ${ }^{16,115}$

HMPV-specific human monoclonal antibodies analogous to palivizumab have shown prophylactic and therapeutic efficacy in rodent models. ${ }^{16,117}$ Strikingly, some of these monoclonal antibodies exhibit broadly neutralizing activity in vitro and in vivo against RSV as well as HMPV. ${ }^{79,118} \mathrm{~A}$ live attenuated vaccine has been tested in humans, although only $\sim 30 \%$ developed a neutralizing antibody response. ${ }^{119}$ Thus, several potential vaccine candidates and prophylactic antibodies are in development, offering potential future intervention in premature infants.

Infection control is an important aspect of HMPV prevention in premature infants. HMPV can persist as infectious particles for hours on nonporous surfaces, ${ }^{120}$ and thus environmental cleaning and personal protective equipment are important to reduce the risk of nosocomial transmission. While there are few reports as yet of nosocomial HMPV in the NICU, multiple reports exist of nosocomial outbreaks of HMPV in long-term care facilities for children and adults. ${ }^{121-124}$ Healthy adults can be productively reinfected with HMPV under experimental conditions, ${ }^{119}$ illustrating the potential for health care worker transmission. However, a 1-year prospective study of 170 pediatric health care workers detected only one episode of HMPV shedding in a subject with cough and rhinorrhea. ${ }^{125}$

\section{Conclusion}

HMPV is a recently identified paramyxovirus, yet it is a leading cause of LRI in children and adults. Premature infants are at high risk of viral LRI and chronic lung disease related to prematurity. Although the data are limited thus far, HMPV is clearly an important respiratory pathogen among these preterm infants. Clinical features are similar to RSV, and the virus may be associated with long-term sequelae. Nosocomial infections likely occur but are underappreciated. Future studies are needed to fully define the burden of disease due to HMPV in preterm infants and to develop therapeutic or preventive strategies for this highrisk population.

\section{Acknowledgments}

The authors were supported by grants NIH HD074736 and HD081120 (NLM) and R01 AI085062 (JVW).

\section{Disclosure}

JVW serves on the Scientific Advisory Board of Quidel and an Independent Data Monitoring Committee for 
GlaxoSmithKline, which have no relationship to the present work. The authors report no other conflicts of interest in this work.

\section{References}

1. van den Hoogen BG, de Jong JC, Groen J, et al. A newly discovered human pneumovirus isolated from young children with respiratory tract disease. Nat Med. 2001;7(6):719-724.

2. Cook JK. Avian pneumovirus infections of turkeys and chickens. Vet J. 2000;160(2):118-125.

3. Yang CF, Wang CK, Tollefson SJ, et al. Genetic diversity and evolution of human metapneumovirus fusion protein over twenty years. Virol J. 2009;6:138.

4. de Graaf M, Osterhaus AD, Fouchier RA, Holmes EC. Evolutionary dynamics of human and avian metapneumoviruses. J Gen Virol. 2008;89(Pt 12):2933-2942.

5. Yang CF, Wang CK, Tollefson SJ, et al. Human metapneumovirus G protein is highly conserved within but not between genetic lineages. Arch Virol. 2013;158(6):1245-1252.

6. Velayudhan BT, Nagaraja KV, Thachil AJ, Shaw DP, Gray GC, Halvorson DA. Human metapneumovirus in turkey poults. Emerg Infect Dis. 2006;12(12):1853-1859.

7. van den Hoogen BG, Herfst S, Sprong L, et al. Antigenic and genetic variability of human metapneumoviruses. Emerg Infect Dis. 2004;10(4):658-666.

8. Aberle JH, Aberle SW, Redlberger-Fritz M, Sandhofer MJ, PopowKraupp T. Human metapneumovirus subgroup changes and seasonality during epidemics. Pediatr Infect Dis J. 2010;29(11):1016-1018.

9. Williams JV, Harris PA, Tollefson SJ, et al. Human metapneumovirus and lower respiratory tract disease in otherwise healthy infants and children. N Engl J Med. 2004;350(5):443-450.

10. Pavlin JA, Hickey AC, Ulbrandt N, et al. Human metapneumovirus reinfection among children in Thailand determined by ELISA using purified soluble fusion protein. J Infect Dis. 2008;198(6):836-842.

11. Ebihara T, Endo R, Ishiguro N, Nakayama T, Sawada H, Kikuta H. Early reinfection with human metapneumovirus in an infant. J Clin Microbiol. 2004;42(12):5944-5946.

12. Erickson JJ, Gilchuk P, Hastings AK, et al. Viral acute lower respiratory infections impair CD8+ T cells through PD-1. J Clin Invest. 2012;122(8):2967-2982.

13. Falsey AR, Hennessey PA, Formica MA, Criddle MM, Biear JM, Walsh EE. Humoral immunity to human metapneumovirus infection in adults. Vaccine. 2010;28(6):1477-1480.

14. van den Hoogen BG, Herfst S, de Graaf M, et al. Experimental infection of macaques with human metapneumovirus induces transient protective immunity. J Gen Virol. 2007;88(Pt 4):1251-1259.

15. Skiadopoulos MH, Biacchesi S, Buchholz UJ, et al. The two major human metapneumovirus genetic lineages are highly related antigenically, and the fusion $(\mathrm{F})$ protein is a major contributor to this antigenic relatedness. J Virol. 2004;78(13):6927-6937.

16. Wen SC, Schuster JE, Gilchuk P, Boyd KL, Joyce S, Williams JV. Lung CD8+ T cell impairment occurs during human metapneumovirus infection despite virus-like particle induction of functional CD8+ T cells. J Virol. 2015;89(17):8713-8726.

17. Williams JV, Wang CK, Yang CF, et al. The role of human metapneumovirus in upper respiratory tract infections in children: a 20-year experience. J Infect Dis. 2006;193(3):387-395.

18. Wei HY, Tsao KC, Huang CG, Huang YC, Lin TY. Clinical features of different genotypes/genogroups of human metapneumovirus in hospitalized children. J Microbiol Immunol Infect. 2013;46(5):352-357.

19. Schuster JE, Khuri-Bulos N, Faouri S, et al. Human metapneumovirus infection in Jordanian children: epidemiology and risk factors for severe disease. Pediatr Infect Dis J. 2015;34(12):1335-1341.

20. Osterhaus A, Fouchier R. Human metapneumovirus in the community. Lancet. 2003;361(9361):890-891.
21. van den Hoogen BG, Osterhaus DM, Fouchier RA. Clinical impact and diagnosis of human metapneumovirus infection. Pediatr Infect Dis J. 2004;23(1 Suppl):S25-S32.

22. Thanasugarn W, Samransamruajkit R, Vanapongtipagorn P, et al. Human metapneumovirus infection in Thai children. Scand J Infect Dis. 2003;35(10):754-756.

23. Williams JV, Tollefson SJ, Heymann PW, Carper HT, Patrie J, Crowe JE. Human metapneumovirus infection in children hospitalized for wheezing. J Allergy Clin Immunol. 2005;115(6):1311-1312.

24. Edwards KM, Zhu Y, Griffin MR, et al. Burden of human metapneumovirus infection in young children. $N$ Engl J Med. 2013;368(7): 633-643.

25. Jain S, Williams DJ, Arnold SR, et al. Community-acquired pneumonia requiring hospitalization among US children. $N$ Engl J Med. 2015;372(9):835-845.

26. Self WH, Williams DJ, Zhu Y, et al. Respiratory viral detection in children and adults: comparing asymptomatic controls and patients with community-acquired pneumonia. J Infect Dis. 2016;213(4):584-591.

27. Boivin G, De Serres G, Cote S, et al. Human metapneumovirus infections in hospitalized children. Emerg Infect Dis. 2003;9(6): 634-640.

28. Esper F, Martinello RA, Boucher D, et al. A 1-year experience with human metapneumovirus in children aged $<5$ years. $J$ Infect Dis. 2004;189(8):1388-1396.

29. Maggi F, Pifferi M, Vatteroni M, et al. Human metapneumovirus associated with respiratory tract infections in a 3-year study of nasal swabs from infants in Italy. J Clin Microbiol. 2003;41(7):2987-2991.

30. Peiris JS, Tang WH, Chan KH, et al. Children with respiratory disease associated with metapneumovirus in Hong Kong. Emerg Infect Dis. 2003;9(6):628-633

31. Garcia-Garcia ML, Calvo C, Martin F, Perez-Brena P, Acosta B, Casas I. Human metapneumovirus infections in hospitalised infants in Spain. Arch Dis Child. 2006;91(4):290-295.

32. Williams JV, Edwards KM, Weinberg GA, et al. Population-based incidence of human metapneumovirus infection among hospitalized children. J Infect Dis. 2010;201(12):1890-1898.

33. Chano F, Rousseau C, Laferriere C, Couillard M, Charest H. Epidemiological survey of human metapneumovirus infection in a large pediatric tertiary care center. J Clin Microbiol. 2005;43(11):5520-5525.

34. Kim YK, Lee HJ. Human metapneumovirus-associated lower respiratory tract infections in Korean infants and young children. Pediatr Infect Dis J. 2005;24(12):1111-1112.

35. Klein MI, Coviello S, Bauer G, et al. The impact of infection with human metapneumovirus and other respiratory viruses in young infants and children at high risk for severe pulmonary disease. J Infect Dis. 2006;193(11):1544-1551.

36. Sasaki A, Suzuki H, Saito R, et al. Prevalence of human metapneumovirus and influenza virus infections among Japanese children during two successive winters. Pediatr Infect Dis J. 2005;24(10):905-908.

37. Dollner H, Risnes K, Radtke A, Nordbo SA. Outbreak of human metapneumovirus infection in Norwegian children. Pediatr Infect Dis J. 2004;23(5):436-440.

38. Ebihara T, Endo R, Kikuta H, et al. Human metapneumovirus infection in Japanese children. J Clin Microbiol. 2004;42(1):126-132.

39. König B, König W, Arnold R, Werchau H, Ihorst G, Forster J. Prospective study of human metapneumovirus infection in children less than 3 years of age. J Clin Microbiol. 2004;42(10):4632-4635.

40. McAdam AJ, Hasenbein ME, Feldman HA, et al. Human metapneumovirus in children tested at a tertiary-care hospital. J Infect Dis. 2004;190(1):20-26.

41. Bosis S, Esposito S, Niesters HG, Crovari P, Osterhaus AD, Principi N. Impact of human metapneumovirus in childhood: comparison with respiratory syncytial virus and influenza viruses. $J$ Med Virol. 2005;75(1):101-104.

42. Freymouth F, Vabret A, Legrand L, et al. Presence of the new human metapneumovirus in French children with bronchiolitis. Pediatr Infect Dis J. 2003;22(1):92-94. 
43. Madhi SA, Ludewick H, Abed Y, Klugman KP, Boivin G. Human metapneumovirus-associated lower respiratory tract infections among hospitalized human immunodeficiency virus type 1 (HIV1)-infected and HIV-1-uninfected African infants. Clin Infect Dis. 2003;37(12):1705-1710.

44. van den Hoogen BG, van Doornum GJ, Fockens JC, et al. Prevalence and clinical symptoms of human metapneumovirus infection in hospitalized patients. J Infect Dis. 2003;188(10):1571-1577.

45. Oliveira DB, Durigon EL, Carvalho AC, et al. Epidemiology and genetic variability of human metapneumovirus during a 4-year-long study in Southeastern Brazil. J Med Virol. 2009;81(5):915-921.

46. Anderson EJ, Simoes EA, Buttery JP, et al. Prevalence and characteristics of human metapneumovirus infection among hospitalized children at high risk for severe lower respiratory tract infection. J Pediatric Infect Dis Soc. 2012;1(3):212-222.

47. Mullins JA, Erdman DD, Weinberg GA, et al. Human metapneumovirus infection among children hospitalized with acute respiratory illness. Emerg Infect Dis. 2004;10(4):700-705.

48. Falsey AR. Human metapneumovirus infection in adults. Pediatr Infect Dis J. 2008;27(10 Suppl):S80-S83

49. Walsh EE, Peterson DR, Falsey AR. Human metapneumovirus infections in adults: another piece of the puzzle. Arch Intern Med. 2008;168(22):2489-2496.

50. Martin JA, Hamilton BE, Ventura SJ, Osterman MJK, Mathews TJ. Births: final data for 2011. Natl Vital Stat Rep. 2013;62(1):1-69.

51. Halterman JS, Lynch KA, Conn KM, Hernandez TE, Perry TT, Stevens TP. Environmental exposures and respiratory morbidity among very low birth weight infants at 1 year of life. Arch Dis Child. 2009;94(1):28-32.

52. Vom Hove M, Prenzel F, Uhlig HH, Robel-Tillig E. Pulmonary outcome in former preterm, very low birth weight children with bronchopulmonary dysplasia: a case-control follow-up at school age. J Pediatr. 2014;164(1):40.e4-45.e4.

53. Peacock JL, Marston L, Marlow N, Calvert SA, Greenough A. Neonatal and infant outcome in boys and girls born very prematurely. Pediatr Res. 2012;71(3):305-310.

54. Walsh MC, Wilson-Costello D, Zadell A, Newman N, Fanaroff A. Safety, reliability, and validity of a physiologic definition of bronchopulmonary dysplasia. J Perinatol. 2003;23(6):451-456.

55. Underwood MA, Danielsen, B, Gilbert WM. Cost, causes and rates of rehospitalization of preterm infants. J Perinatol. 2007;27:614-619.

56. Bont L, Blanken M. Viral respiratory burden in moderate-to-late preterm infants. Early Hum Dev. 2013;89 (Suppl 1):S37-S39.

57. Arruda E, Jones MH, Escremim de Paula F, et al. The burden of single virus and viral coinfections on severe lower respiratory tract infections among preterm infants: a prospective birth cohort study in Brazil. Pediatr Infect Dis J. 2014;33(10):997-1003.

58. Taylor JB, Nyp MF, Norberg M, et al. Impact of intercurrent respiratory infections on lung health in infants born $<29$ weeks with bronchopulmonary dysplasia. $J$ Perinatol. 2014;34(3):223-228.

59. Drysdale SB, Alcazar-Paris M, Wilson T, et al. Viral lower respiratory tract infections and preterm infants' healthcare utilisation. Eur $J$ Pediatr. 2015;174(2):209-215.

60. Baraldi E, Filippone M. Chronic lung disease after premature birth. N Engl J Med. 2007;357(19):1946-1955.

61. Broughton S, Sylvester KP, Fox G, et al. Lung function in prematurely born infants after viral lower respiratory tract infections. Pediatr Infect Dis J. 2007;26(11):1019-1024.

62. Drysdale SB, Lo J, Prendergast M, et al. Lung function of preterm infants before and after viral infections. Eur J Pediatr. 2014;173(11): 1497-1504.

63. Pryhuber GS. Postnatal infections and immunology affecting chronic lung disease of prematurity. Clin Perinatol. 2015;42(4):697-718.

64. Faden H, Wynn RJ, Campagna L, Ryan RM. Outbreak of adenovirus type 30 in a neonatal intensive care unit. J Pediatr. 2005;146(4):523-527.

65. Reid AB, Anderson TL, Cooley L, Williamson J, McGregor AR. An outbreak of human rhinovirus species $\mathrm{C}$ infections in a neonatal intensive care unit. Pediatr Infect Dis J. 2011;30(12):1096-1095.
66. Verboon-Maciolek MA, Krediet TG, Gerards LJ, Fleer A, van Loon TM. Clinical and epidemiologic characteristics of viral infections in a neonatal intensive care unit during a 12-year period. Pediatr Infect Dis J. 2005;24(10):901-904.

67. Klemenc J, Asad Ali S, Johnson M, et al. Real-time reverse transcriptase PCR assay for improved detection of human metapneumovirus. J Clin Virol. 2012;54(4):371-375.

68. Ronchi A, Michelow IC, Chapin KC, et al. Viral respiratory tract infections in the neonatal intensive care unit: the VIRIoN-I study. $J$ Pediatr. 2014;165(4):690-696.

69. Kilani RA. Respiratory syncytial virus (RSV) outbreak in the NICU: description of eight cases. J Trop Pediatr. 2002;48(2):118-122.

70. Halasa NB, Williams JV, Wilson GJ, Walsh WF, Schaffner W, Wright PF. Medical and economic impact of a respiratory syncytial virus outbreak in a neonatal intensive care unit. Pediatr Infect Dis J. 2005;24(12):1040-1044.

71. Kurz H, Herbich K, Janata O, Sterniste W, Bauer K. Experience with the use of palivizumab together with infection control measures to prevent respiratory syncytial virus outbreaks in neonatal intensive care units. J Hosp Infect. 2008;70(3):246-252.

72. Dizdar EA, Aydemir C, Erdeve O, et al. Respiratory syncytial virus outbreak defined by rapid screening in a neonatal intensive care unit. $J$ Hosp Infect. 2010;75(4):292-294.

73. O'Connell K, Boo TW, Keady D, et al. Use of palivizumab and infection control measures to control an outbreak of respiratory syncytial virus in a neonatal intensive care unit confirmed by real-time polymerase chain reaction. J Hosp Infect. 2011;77(4):338-342.

74. Silva Cde A, Dias L, Baltieri SR, Rodrigues TT, Takagi NB, Richtmann R. Respiratory syncytial virus outbreak in neonatal intensive care unit: impact of infection control measures plus palivizumab use. Antimicrob Resist Infect Control. 2012;1(1):16.

75. Alan S, Erdeve O, Cakir U, et al; TurkNICU-RSV Trial Group. Outcome of the respiratory syncytial virus related acute lower respiratory tract infection among hospitalized newborns: a prospective multicenter study. J Matern Fetal Neonatal Med. 2016;29(13):2186-2193.

76. Garcia-Garcia ML, Gonzalez-Carrasco E, Quevedo S, et al. Clinical and virological characteristics of early and moderate preterm infants readmitted with viral respiratory infections. Pediatr Infect Dis $J$. 2015;34(7):693-699.

77. Ulloa-Gutierrez R, Skippen P, Synnes A, et al. Life-threatening human metapneumovirus pneumonia requiring extracorporeal membrane oxygenation in a preterm infant. Pediatrics. 2004;114(4): e517-e519.

78. Papenburg J, Hamelin ME, Ouhoummane N, et al. Comparison of risk factors for human metapneumovirus and respiratory syncytial virus disease severity in young children. $J$ Infect Dis. 2012;206(2): 178-189.

79. Schuster JE, Cox RG, Hastings AK, et al. A broadly neutralizing human monoclonal antibody exhibits in vivo efficacy against both human metapneumovirus and respiratory syncytial virus. J Infect Dis. 2015;211(2):216-225.

80. Glezen WP, Frank AL, Taber LH, Kasel JA. Parainfluenza virus type 3: seasonality and risk of infection and reinfection in young children. J Infect Dis. 1984;150(6):851-857.

81. Glezen WP, Taber LH, Frank AL, Kasel JA. Risk of primary infection and reinfection with respiratory syncytial virus. Am J Dis Child. 1986;140(6):543-546.

82. Dunn SR, Ryder AB, Tollefson SJ, Xu M, Saville BR, Williams JV. Seroepidemiologies of human metapneumovirus and respiratory syncytial virus in young children, determined with a new recombinant fusion protein enzyme-linked immunosorbent assay. Clin Vaccine Immunol. 2013;20(10):1654-1656.

83. Lusebrink J, Wiese C, Thiel A, et al. High seroprevalence of neutralizing capacity against human metapneumovirus in all age groups studied in Bonn, Germany. Clin Vaccine Immunol. 2010;17(3):481-484.

84. Palmeira P, Quinello C, Silveira-Lessa AL, Zago CA, Carneiro-Sampaio $\mathrm{M}$. IgG placental transfer in healthy and pathological pregnancies. Clin Dev Immunol. 2012;2012:985646. 
85. Pancham K, Perez GF, Huseni S, et al. Premature infants have impaired airway antiviral IFN $\gamma$ responses to human metapneumovirus compared to respiratory syncytial virus. Pediatr Res. 2015;78(4):389-394.

86. Semple MG, Cowell A, Dove W, et al. Dual infection of infants by human metapneumovirus and human respiratory syncytial virus is strongly associated with severe bronchiolitis. J Infect Dis. 2005;191(3):382-386.

87. van Woensel JB, Bos AP, Lutter R, Rossen JW, Schuurman R. Absence of human metapneumovirus co-infection in cases of severe respiratory syncytial virus infection. Pediatr Pulmonol. 2006;41(9):872-874.

88. Lazar I, Weibel C, Dziura J, Ferguson D, Landry ML, Kahn JS. Human metapneumovirus and severity of respiratory syncytial virus disease. Emerg Infect Dis. 2004;10(7):1318-1320.

89. Singleton RJ, Bulkow LR, Miernyk K, et al. Viral respiratory infections in hospitalized and community control children in Alaska. J Med Virol. 2010;82(7):1282-1290.

90. Weisman L. Populations at risk for developing respiratory syncytial virus and risk factors for respiratory syncytial virus severity: infants with predisposing conditions. Pediatr Infect Dis J. 2003;22(2 Suppl):S33-S37; discussion S37-S39.

91. Melendi GA, Laham FR, Monsalvo AC, et al. Cytokine profiles in the respiratory tract during primary infection with human metapneumovirus, respiratory syncytial virus, or influenza virus in infants. Pediatrics. 2007;120(2):e410-e415.

92. Maitre NL, Ballard RA, Ellenberg JH, et al. Respiratory consequences of prematurity: evolution of a diagnosis and development of a comprehensive approach. J Perinatol. 2015;35(5):313-321.

93. Speer CP. Pulmonary inflammation and bronchopulmonary dysplasia. $J$ Perinatol. 2006;26 (Suppl 1):S57-S62; discussion S63-S64.

94. O'Reilly MA, Marr SH, Yee M, McGrath-Morrow SA, Lawrence BP. Neonatal hyperoxia enhances the inflammatory response in adult mice infected with influenza A virus. Am J Respir Crit Care Med. 2008;177(10):1103-1110.

95. Bhandari V. Hyperoxia-derived lung damage in preterm infants. Semin Fetal Neonatal Med. 2010;15(4):223-229.

96. Baraldi E, Filippone M, Trevisanuto D, Zanardo V, Zacchello F. Pulmonary function until two years of life in infants with bronchopulmonary dysplasia. Am J Respir Crit Care Med. 1997;155(1):149-155.

97. Garcia-Garcia ML, Calvo C, Casas I, et al. Human metapneumovirus bronchiolitis in infancy is an important risk factor for asthma at age 5. Pediatr Pulmonol. 2007;42(5):458-464.

98. Drysdale SB, Prendergast M, Alcazar M, et al. Genetic predisposition of RSV infection-related respiratory morbidity in preterm infants. Eur J Pediatr. 2014;173(7):905-912.

99. Gupta A, Bembea M, Brown A, Robertson C, Romer L, Cohn RD. Respiratory failure secondary to human metapneumovirus requiring extracorporeal membrane oxygenation in a 32-month-old child. Case Rep Pediatr. 2012;2012:268074.

100. Hamelin ME, Prince GA, Boivin G. Effect of ribavirin and glucocorticoid treatment in a mouse model of human metapneumovirus infection. Antimicrob Agents Chemother. 2006;50(2):774-777.

101. Wyde PR, Chetty SN, Jewell AM, Boivin G, Piedra PA. Comparison of the inhibition of human metapneumovirus and respiratory syncytial virus by ribavirin and immune serum globulin in vitro. Antiviral Res. 2003;60(1):51-59.

102. Bonney D, Razali H, Turner A, Will A. Successful treatment of human metapneumovirus pneumonia using combination therapy with intravenous ribavirin and immune globulin. Br J Haematol. 2009; 145(5):667-669.

103. Hopkins P, McNeil K, Kermeen F, et al. Human metapneumovirus in lung transplant recipients and comparison to respiratory syncytial virus. Am J Respir Crit Care Med. 2008;178(8):876-881.

104. Kamble RT, Bollard C, Demmler G, LaSala PR, Carrum G. Human metapneumovirus infection in a hematopoietic transplant recipient. Bone Marrow Transplant. 2007;40(7):699-700.

105. Raza K, Ismailjee SB, Crespo M, et al. Successful outcome of human metapneumovirus (hMPV) pneumonia in a lung transplant recipient treated with intravenous ribavirin. J Heart Lung Transplant. 2007;26(8):862-864
106. Kitanovski L, Kopriva S, Pokorn M, et al. Treatment of severe human metapneumovirus (hMPV) pneumonia in an immunocompromised child with oral ribavirin and IVIG. J Pediatr Hematol Oncol. 2013; 35(7):e311-e313.

107. Shahda S, Carlos WG, Kiel PJ, Khan BA, Hage CA. The human metapneumovirus: a case series and review of the literature. Transpl Infect Dis. 2011;13(3):324-328.

108. Tang RS, Mahmood K, Macphail M, et al. A host-range restricted parainfluenza virus type 3 (PIV3) expressing the human metapneumovirus (hMPV) fusion protein elicits protective immunity in African green monkeys. Vaccine. 2005;23(14):1657-1667.

109. Palavecino CE, Cespedes PF, Gomez RS, Kalergis AM, Bueno SM. Immunization with a recombinant bacillus Calmette-Guerin strain confers protective Th1 immunity against the human metapneumovirus. J Immunol. 2014;192(1):214-223.

110. Biacchesi S, Pham QN, Skiadopoulos MH, Murphy BR, Collins PL, Buchholz UJ. Infection of nonhuman primates with recombinant human metapneumovirus lacking the $\mathrm{SH}, \mathrm{G}$, or M2-2 protein categorizes each as a nonessential accessory protein and identifies vaccine candidates. J Virol. 2005;79(19):12608-12613.

111. Buchholz UJ, Biacchesi S, Pham QN, et al. Deletion of M2 gene open reading frames 1 and 2 of human metapneumovirus: effects on RNA synthesis, attenuation, and immunogenicity. J Virol. 2005;79(11): 6588-6597.

112. Herfst S, de Graaf M, Schrauwen EJ, et al. Generation of temperaturesensitive human metapneumovirus strains that provide protective immunity in hamsters. J Gen Virol. 2008;89(Pt 7):1553-1562.

113. Herfst S, Schrauwen EJ, de Graaf M, et al. Immunogenicity and efficacy of two candidate human metapneumovirus vaccines in cynomolgus macaques. Vaccine. 2008;26(33):4224-4230.

114. Cox RG, Erickson JJ, Hastings AK, et al. Human metapneumovirus virus-like particles induce protective $\mathrm{B}$ and $\mathrm{T}$ cell responses in a mouse model. J Virol. 2014;88(11):6368-6379.

115. Levy C, Aerts L, Hamelin ME, et al. Virus-like particle vaccine induces cross-protection against human metapneumovirus infections in mice. Vaccine. 2013;31(25):2778-2785.

116. Ulbrandt ND, Ji H, Patel NK, et al. Isolation and characterization of monoclonal antibodies which neutralize human metapneumovirus in vitro and in vivo. J Virol. 2006;80(16):7799-7806.

117. Williams JV, Chen Z, Cseke G, et al. A recombinant human monoclonal antibody to human metapneumovirus fusion protein that neutralizes virus in vitro and is effective therapeutically in vivo. J Virol. 2007;81(15):8315-8324.

118. Corti D, Bianchi S, Vanzetta F, et al. Cross-neutralization of four paramyxoviruses by a human monoclonal antibody. Nature. 2013; 501(7467):439-443.

119. Talaat KR, Karron RA, Thumar B, et al. Experimental infection of adults with recombinant wild-type human metapneumovirus. J Infect Dis. 2013;208(10):1669-1678.

120. Tollefson SJ, Cox RG, Williams JV. Studies of culture conditions and environmental stability of human metapneumovirus. Virus Res. 2010;151(1):54-59.

121. Boivin G, De Serres G, Hamelin ME, et al. An outbreak of severe respiratory tract infection due to human metapneumovirus in a longterm care facility. Clin Infect Dis. 2007;44(9):1152-1158.

122. Louie JK, Schnurr DP, Pan CY, et al. A summer outbreak of human metapneumovirus infection in a long-term-care facility. J Infect Dis. 2007;196(5):705-708.

123. Neu N, Plaskett T, Hutcheon G, Murray M, Southwick KL, Saiman L. Epidemiology of human metapneumovirus in a pediatric long-term care facility. Infect Control Hosp Epidemiol. 2012;33(6):545-550.

124. Matsuda S, Nakamura M, Hirano E, et al. Characteristics of human metapneumovirus infection prevailing in hospital wards housing patients with severe disabilities. Jpn J Infect Dis. 2013;66(3):195-200.

125. Esbenshade JC, Edwards KM, Esbenshade AJ, et al. Respiratory virus shedding in a cohort of on-duty healthcare workers undergoing prospective surveillance. Infect Control Hosp Epidemiol. 2013; 34(4):373-378. 
Research and Reports in Neonatology

\section{Publish your work in this journal}

Research and Reports in Neonatology is an international, peer-reviewed, open access journal publishing original research, reports, editorials, reviews and commentaries on neonatal health. The manuscript management system is completely online and includes a very quick and fair

Submit your manuscript here: https://www.dovepress.com/research-and-reports-in-neonatology-journal 